\title{
A Probe into the Methods of Training Students' Ability to Solve Practical Problems in the Teaching of Applied Questions in Primary Schools
}

\author{
Pahini Dma \\ Universitas Pendidikan Ganesha, Jl. Udayana 11 Singaraja, Buleleng, Bali, Indonesia \\ diahprema97@gmail.com
}

\begin{abstract}
This study aims to describe the improvement of mathematical problem solving skills assisted by project - based worksheets. This research is classroom action research conducted in three cycles. The research subjects were 10 students of class VII SMP Negeri 1 Kuta Utara. The research data were analyzed descriptively and qualitatively. The results showed that there was an increase in mathematical problem solving abilities. This can be seen when students present in front of the class, students who have low problem solving skills are able to identify what is known, asked, and use mathematical concepts according to the problem. This increase occurred due to the use of project - based worksheets to solve problems of daily life so as to make learning more meaningful
\end{abstract}

Keywords: Student Worksheet based on project, mathematical problem solving ability

\section{Introduction}

Education is a process that involves three dimensions, namely the individual, society and national community of the individual concerned and plays a role in the formation of human nature and society. Education is more than just teaching, which can be said as a process of knowledge transfer, value transformation, and personality formation with all the aspects it includes. Thus, teaching is more oriented to the formation of specialists or certain fields, therefore the attention and interest is more technical (Nurkholis, 2013). The importance of education in ensuring human survival because education is a means to improve and develop the quality of human resources so that human life is directed. The government is expected to improve the quality of education in Indonesia which has now been realized in learning in schools involving students, teachers, methods, objectives, curriculum, media, facilities, principals, government, community, physical environment. With this, an effective learning atmosphere is created and can develop human capacity to the fullest.

The purpose of national education as stated in Law No.20 of 2003 (BSNP, 2016) is that national education is used to build the character and capabilities and civilization of a dignified nation in the context of educating the nation, aiming to develop the potential of students to become human beings who believe and fear God. God Almighty, has noble character, is healthy, knowledgeable, capable, creative, independent, and becomes a democratic and responsible citizen. As a very important aspect, education is one of the most important aspects that requires us to quickly adapt and solve problems quickly and carefully with various different points of view, so it is necessary to have good problem solving skills in solving these problems. This problem can be solved by studying mathematics. Therefore, mathematics is given starting from elementary school level even up to college in order to think logically, analytically, systematically, critically, and creatively (BSNP, 2016).
The National Council of Teacher Mathematics (NCTM, 2000), NCTM states that there are 5 abilities that must be mastered by students through learning mathematics, namely: (1) problem solving (problem solving); (2) reasoning and proof (reasoning and proof); (3) connection (connection); (4) communication, and (5) representation. Problem solving ability is one of the main focuses of mathematics learning objectives.

Based on the results of interviews and observations made to class teachers and class VII students of SMPN 1 Kuta Utara on April 27, it was found that students did not understand the presentation of questions in the form of story questions which contained problems of everyday life. One of the difficulties experienced by students is modeling this problem in the form of a mathematical model. Students are required to be able to think creatively and be able to relate the concepts they have learned and be able to find solutions to the problems they face. With this problem, students' solving abilities are very important to explore because they are still very lacking.

In helping students relate their knowledge to the problems they face, teachers are advised to combine it with project based learning.

Online learning will certainly be less meaningful without the synergy of appropriate learning strategies and methods. One application that can integrate online learning is project based learning. The main component of project - based learning is asking questions or problems that are presented to compose and start activities that emphasize a number of projects until a final result is obtained in the form of a product as a series of individual communication activities or various task results that answer questions. So that through project - based learning it provides opportunities for students to learn concepts in depth while also increasing their learning outcomes. As Suci Lestari and Arizona (2018) state, project - based learning is an in - depth investigation of a topic from the real world. A well - designed project asks students to tackle real problems and important issues that 
occur in everyday life, especially in the learning process. Thus, the projects that students build are based on observations of real - world problems around them that will provide meaning for them. Based on this, it is necessary to have effective learning applied to students to increase their competence. Moreover, due to the impact of the Covid - 19 pandemic that hit so that learning did not run optimally because they had to stay at home and implement physical distancing. So that project - based online learning is one solution to the problems faced to answer this problem.

According to Suyitno (in FeridaAryani, 2011) states that student worksheet is the right learning alternative for students because it can help students to add information about the concepts learned through systematic learning activities. Through student worksheet by utilizing an ethnomathematical approach that is oriented to local wisdom, it is expected to be able to improve mathematical problem solving abilities and foster nationalism and religious attitudes in seventh grade students of SMP Negeri 1 Kuta Utara. So, this research is entitled Application of Project - Based Mathematics Student Worksheet to Improve Students' Problem - Solving Ability.

\section{Methodology}

\section{Research design}

The research carried out is collaborative classroom action research which generally aims to improve and improve the quality, process, and outcomes of learning mathematics in the classroom. This research was conducted in 3 (three) cycles. In this study, the CAR used was the Kurt Lewin model. According to Kurt Lewin (in Sanjaya, 2013) each cycle consists of 4 (four) stages, namely action planning, action implementation, observation and evaluation and reflection. Mathematical problem solving ability is measured through a mathematical problem solving ability test in the form of a description given at the end of each cycle.

\section{Population and sampling}

Respondents from this study came from 10 students of class VII G SMPN 1 Kuta Utara. These respondents were selected randomly. Simple random sampling was used in selecting the student respondents of the study. These procedures were used when the subsets of individual were chosen from a larger group of population

\section{Source Data}

The sources of data refer to the problem solving test which is presented in the form of student worksheets, interviews and observations. This student worksheet is given at each meeting, namely student worksheet with different material in one chapter. After obtaining the score from this worksheet, it is presented in the form of a line diagram showing the students' problem solving abilities increasing or decreasing.

\section{Interview}

In reconstruction of the experiences and what happened, interviews are concerned with the facts and sequence of an event (McNamara, 1999). A guide for an interview were followed to find out the possible issues and concerns of students in using Student Worksheet in online learning. This would help to examine or develop and suggest improvements from the evaluation dealing with incorrect behaviours.

\section{Observation}

To see clearly what happened in the actual usage of virtual rather than depending on the respondents. Thus, the researcher explored what meant on and enhanced the understanding of various kinds of interaction, as part of research.

\section{Results and Discussion}

Class VII students of SMP Negeri 1 Kuta Utara are given an initial test in the form of a description question at the initial reflection stage. Pre - test is given to get a clearer picture of the problems in learning mathematics that occur in the class. This is a follow - up to the results of observations and interviews with teachers as described in the background. The results of the data analysis of students' mathematical problem - solving abilities before the implementation of the action showed that the highest score in the Pre - Test was 80 and the lowest score in the Pre - Test was 50. The percentage of the number of students whose initial test scores had not been completed was $70.00 \%$, namely 7 people. The results of the initial test of students' problem solving abilities can be presented in Figure 1.

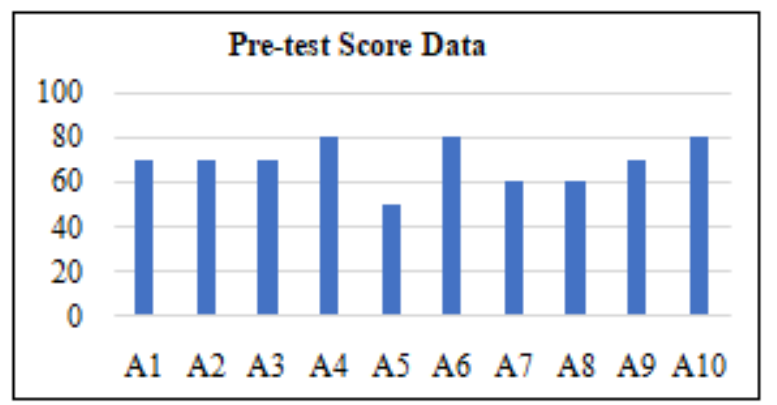

Figure 1: Graph of the distribution of the results of the mathematical problem solving ability test in the Pre - Test Negeri 1 Kuta Utara still does not meet the indicators that have been set.

At the end of first Cycle students are given a mathematical problem solving ability test. The results of the student problem solving ability test are presented in Figure 2

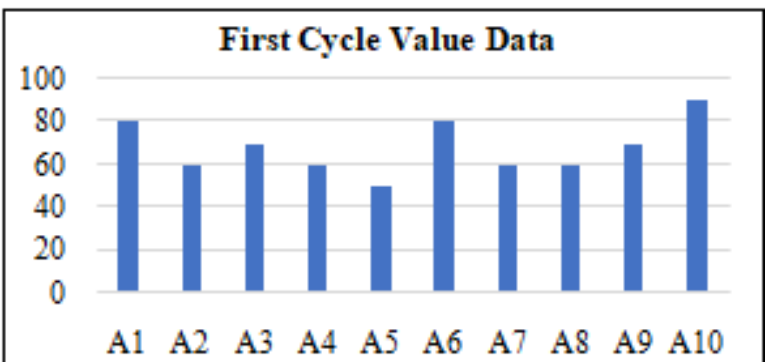

Figure 2: Graph of Students' Mathematical Problem Solving Ability Test Results in first Cycle.

It can be concluded that the mathematical problem solving ability of the seventh grade students of SMP Negeri 1 Kuta Utara in the first cycle has met the KKM that has been set by the school. However, the students' mathematical problem 
solving ability was better than the results of the initial test given earlier.

At the end of second Cycle students were given a test of mathematical problem solving ability. From the analysis of the data, it was obtained that the average values were as follows.

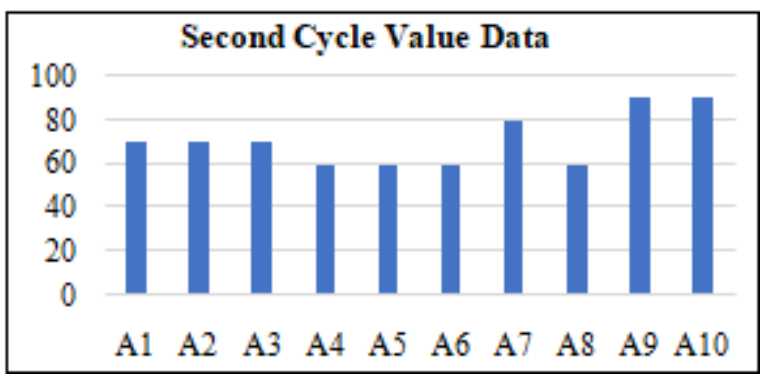

Graph of Students' Mathematical Problem Solving Ability Test Results in Cycle

It can be concluded that the mathematical problem solving ability of the seventh grade students of SMP Negeri 1 Kuta Utara in the second cycle has met the KKM that has been set by the school. However, students' mathematical problem solving abilities were better than the results of the first cycle test given previously.

At the end of Cycle III students were given a test of mathematical problem solving ability. From the data analysis, it was obtained an average score of 74 with the percentage of students who completed $80.00 \%$, namely 8 out of 10 students who were able to achieve the indicator.

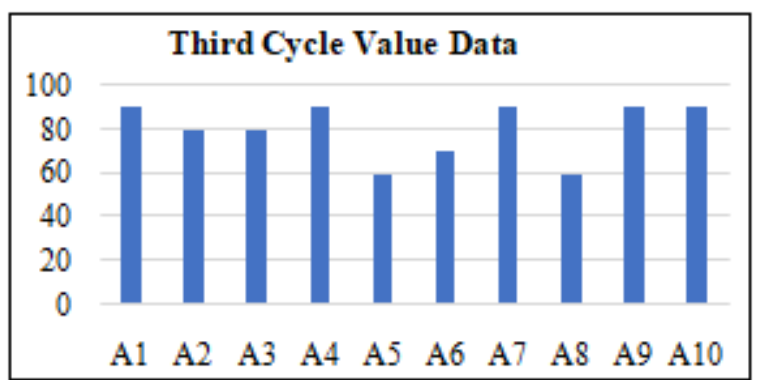

It can be concluded that the mathematical problem solving ability of the seventh grade students of SMP Negeri 1 Kuta Utara in the third cycle has met the KKM set by the school. This can also be seen from the results of observations in the classroom where students with low problem solving abilities are able to identify what is known, asked, and use mathematical concepts according to the problem.

The increase in the average value of students' mathematical problem solving abilities at the initial reflection stage, cycle I, cycle II, and cycle III can be presented in Fig.

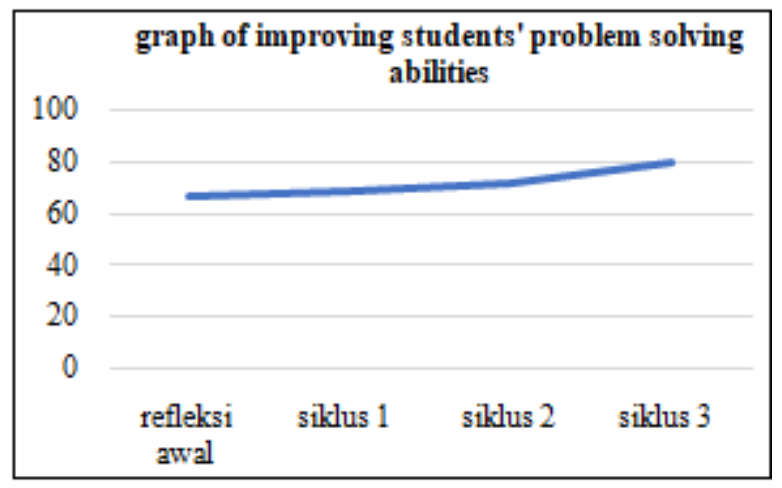

Based on the results of research carried out for three cycles it has shown that there is an increase in the mathematical problem solving ability of seventh grade students of SMP Negeri 1 Kuta Utara through project - based student worksheet - assisted learning. The percentage of students with mathematical problem solving abilities who are in the complete category increases from cycle to cycle.

First, researchers in the learning process apply project based learning which is described in the form of story questions on the student worksheet. Project learning provides opportunities for students to design assignments and retrieve information to be implemented in everyday life. Project learning helps students gain a variety of experiences, knowledge, skills and attitudes. Student motivation can be increased through project - based learning (Handayani 2020). The use of worksheets invites students to understand abstract mathematical concepts with real objects found in everyday life, especially those that contain project elements, so that mathematics learning becomes more meaningful. With meaningful learning, students not only memorize formulas but understand mathematical concepts in learning, making students able to understand problems, formulate problems, choose the right ideas and strategies to plan problem solving (Nurfarikhin, 2010). Then, the research conducted by Parwati (2011), states that the implementation of problem solvinglearning strategies begins with presenting problems that are in accordance with students' daily life situations (contextual problems) to the discovery of concepts independently by students. Contextual problems are presented as a stimulus, then students are gradually guided to master the concept of the material being studied. And understanding the problems of everyday life and even being able to find solutions is a form of students' concern for the surrounding environment.

Second, the teacher ensures that each group is serious in doing each task given to create a relevant product. Students are given the opportunity to practice solving the problems of everyday life that exist in the student worksheet. Each student must be ready to present the results of their discussion. The teacher directs group representatives to explain the results of their group work, this motivates students to dare to have an opinion and be able to solve the problems given.

Third, the teacher provides guidance and knowledge to students with project - based worksheets that present problems as projects and products as solutions. Integrating the problems of everyday life in the learning process can 
instil a sense of concern for students towards the surrounding environment.

At the beginning of the implementation of the first cycle, some students still had difficulty in working on the problems given. Students still have difficulty understanding, formulating, interpreting the problem into simpler sentences. Students do not participate actively in the learning process because students are still confused about understanding and formulating problems. Based on the results of reflection, the teacher motivates students to read each problem well, formulate problems, interpret problems in written form, understand ideas and apply appropriate strategies to solve problems. Based on the obstacles faced, the teacher and the researcher reflected on the problems faced in the first cycle. The teacher also motivated students to be more active in participating in expressing their opinions according to their respective abilities and understandings.

In the implementation of cycle II, the discussion process runs more optimally. Students are able to express opinions and ask questions in group discussions. Most students are able to formulate problems, interpret problems, and plan problem solving with appropriate strategies. When students have difficulty working on problems in the student worksheet, students are not reluctant to ask directly to the teacher or their friends.

In the implementation of cycle III, students participate more actively in learning, often express their opinions, and respond to problems so as to increase students' creative thinking which is directly proportional to the increase in students' mathematical problem solving abilities. Students become more active and more enthusiastic in learning.

The increase in students' mathematical problem solving abilities occurs due to the implementation of actions in each cycle by applying project - based student worksheet assisted learning during learning and providing improvements. improvement in each cycle as an effort to overcome the obstacles that occur during implementing project - based student worksheet assisted learning.

The application of the ethnomathematics - based Student Worksheet - assisted learning model in mathematics learning in class VII SMP Negeri 1 Kuta Utara is going well, the obstacles encountered can be overcome through reflection on each learning process and each cycle, so that the applied learning has improved students' mathematical problem solving abilities.

Thus, the classroom action research that was carried out succeeded in meeting all the indicators of success that had been set

\section{Conclusions and Suggestions}

From the findings of this study, the following conclusions are drawn. In general, the mathematical problem solving ability of grade VII students of SMP Negeri 1 Kuta Utara in the 2020/2021 academic year through the application of project - based student worksheet - assisted learning has increased from cycle to cycle.

\section{Recommendation}

Based on the findings and conclusions, the following recommendations are made:

1) Researchers hope that teachers can apply student worksheet - assisted learning more intensively at each meeting

2) Teachers are expected to provide a more challenging project for students to develop students' problem solving skills

3) Teachers are expected to guide students in working on projects and encourage students to think creatively and innovatively.

\section{References}

[1] Nurkholis.2013. Pendidikan Dalam Upaya Memajukan Teknologi. Jurnal Kependidikan, Vol.1 No.1 November 2013

[2] NCTM.2000. Principles and Standards for School Mathematics. (Online) (http: //www.nctm. org/standards/focalpoints. aspx?id=284, Diaksestgl.28 April 2019)

[3] BNSP. Standar Isi dan Standar Kompetensi Lulusan SD/MI. Jakarta: Kemendiknas, 2006.

[4] Sucilestari, R. \& Arizona, K. (2018). Pengaruh Project Based Learning pada MatakuliahElektronika Dasar terhadapKecakapanHidupMahasiswa Prodi TadrisFisika UIN Mataram. KonstanJurnalFisika dan Pendidikan Fisika, 3 (1), 26 - 35. https: //jurnalkonstan. ac. id/index. php/jurnal/arti cle/view/4 DOI: https: //doi. org/10.20414/konstan. v3i1.4

[5] Farida Aryani\& Cecil Hiltrimartin, "Jurnal Pendidikan Matematika: Pengembangan STUDENT WORKSHEET Untuk Metode PenemuanTerbimbing Pada Pembelajaran Matematika Kelas VIII Di SMP Negeri 18 Palembang". Unsri, Vol.5, No.2, Juli 2011, hlm 13

[6] Sanjaya, Wina.2013. Penelitian Pendidikan Jenis, Metode, dan Prosedur. Jakarta: Prenada Media Group

[7] Handayani, Lilik.2020. "Peningkatan Motivasi Belajar Ipa Melalui Model Pembelajaran Project Based Learning Pada Masa Pandemi Covid - 19 Bagi SiswaSmp Negeri 4 Gunungsari. "JurnalPaedagogy : JurnalPenelitian Dan Pengembangan Pendidikan 7 (3): 168-74

[8] Nurfarikhin, Faud.2010. Hubungan Kemampuan Pemahaman Konsep Dan Kemampuan Penalaran Dengan KemampuanPemecahanMasalah Pada MateriBangun Ruang Sisi LengkungPesertaDidik Kelas IX MTs NU 24 DarulUlumPidodoKulonPatebon Kendal. Skripsi (tidakditerbitkan). Semarang: Institut Agama Islam Negeri Walisongo.

[9] Parwati, N. N.2011. Pengaruh Strategi Pembelajaran dan Jenis Masalahterhadap Kemampuan Pemecahan Masalah pada Siswa SD yang Memiliki Sikap Berbedaterhadap Matematika. Disertasi, Program Studi Teknologi Pembelajaran. Program Pascasarjana: Universitas Negeri Malang 